\title{
Anchoring bias in a case of recurrent abdominal pain
}

\author{
Scott Keeney, ${ }^{1}$ Alexandra Halalau ${ }^{2}$
}

${ }^{1}$ Internal Medicine, Beaumont Health System, Royal Oak, Michigan, USA

${ }^{2}$ Beaumont Health System, Oakland University William Beaumont School of Medicine, Rochester, Michigan, USA

\section{Correspondence to} Dr Scott Keeney,

Scott.Keeney@beaumont.edu

Accepted 21 September 2017

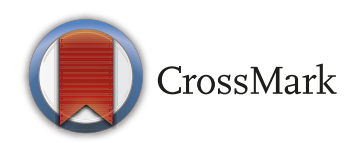

To cite: Keeney $S$, Halalau $A$. BMJ Case Rep Published Online First: [please include Day Month Year]. doi:10.1136/bcr-2017221027

\section{DESCRIPTION}

A 43-year-old man with a history of idiopathic acute pancreatitis and pancreatic pseudocysts presented to the hospital with acute abdominal pain, vomiting and hypotension. He had been hospitalised on multiple occasions for recurrent, self-limited abdominal pain accompanied by hypotension. Given his history, the symptoms were typically attributed to acute chronic pancreatitis, despite absence of lipase elevation and pancreatic pathology on cross-sectional imaging. He had received multiple imaging studies and was scheduled for an elective cholecystectomy as biliary colic was a suspected aetiology for his symptoms.

On hospital presentation, lipase level was $12 \mathrm{U} / \mathrm{L}(10-65 \mathrm{U} / \mathrm{L})$ and a CT of the abdomen demonstrated ascites and intestinal oedema without pancreatic inflammation or calcification (figure 1). Empiric antibiotics were initiated. On further enquiry, the patient described intermittent swelling of his extremities without urticaria for years and provided a picture of his swollen hand during one of these episodes (figure 2). Additionally, family history disclosed that two of his siblings were diagnosed with hereditary angioedema and thus suspicion for this condition was raised. A screening C4 level was $<6 \mathrm{mg} /$ $\mathrm{dL}(12-43 \mathrm{mg} / \mathrm{dL})$ and a C1-inhibitor level was $5 \mathrm{mg} / \mathrm{dL}(19-37 \mathrm{mg} / \mathrm{dL})$, confirming the diagnosis of type 1 hereditary angioedema due to C1-inhibitor deficiency (C1-INH-HAE). The patient improved with supportive care and was referred to an immunologist.

C1-INH-HAE is a rare genetic disorder with an autosomal dominant inheritance pattern characterised by recurrent attacks of oedema involving various organ systems including the skin, respiratory mucosa and intestinal tract. ${ }^{1}$

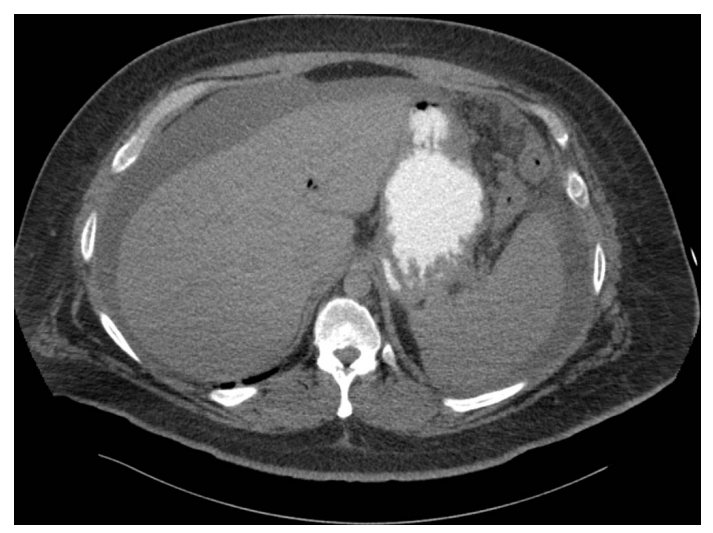

Figure 1 Ascites and intestinal oedema during an attack of hereditary angioedema.

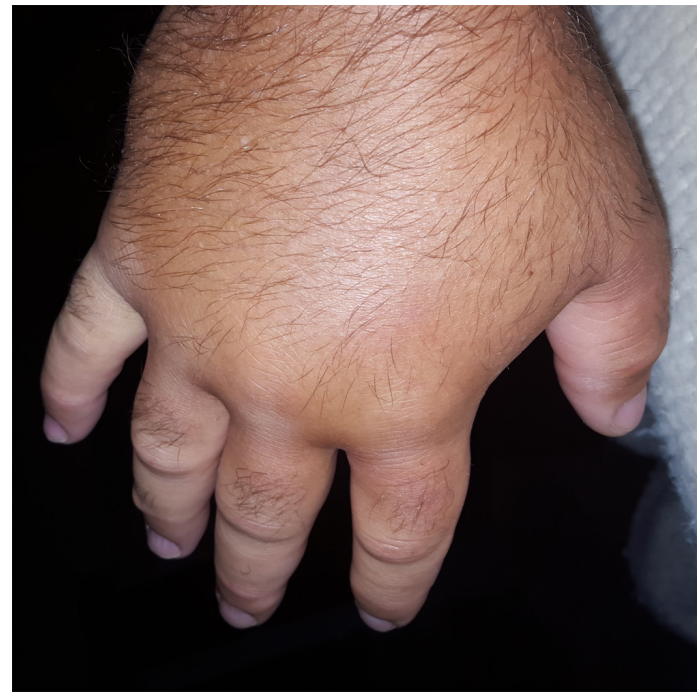

Figure 2 Diffuse hand swelling during an attack of hereditary angioedema

The pathophysiology of angioedema in this condition is related to loss of C1-inhibitor-mediated control of the plasma kallikrein-kinin (contact) system, the downstream effect being excess bradykinin release and thus vascular permeability and oedema. Additionally, C1-inhibitor controls activation of the complement cascade and its deficiency leads to a permanent reduction in C4 levels. As a result, C4 is the recommended screening test as its level will be low even between attacks. ${ }^{2}$ There are two variants of C1-inhibitor: deficiency (type 1) or dysfunction (type 2). ${ }^{2}$ If $\mathrm{C} 4$ is low and C1-inhibitor is less than $50 \%$ of normal, the patient has type $1 \mathrm{C} 1-\mathrm{INH}-\mathrm{HAE}$. If $\mathrm{C} 4$ is low and the C1-inhibitor level is normal or high, the diagnosis of type 2 C1-INH-HAE is made by demonstrating reduced activity of $\mathrm{C} 1$-inhibitor. ${ }^{2}$ Treatment involves avoidance of triggers (trauma, infectious disease, stress), ${ }^{1}$ on demand subcutaneous or intravenous therapies for acute attacks, and prophylactic therapy if attacks are frequent or severe enough. ${ }^{2}$

Hereditary angioedema is an infrequent cause of recurrent abdominal pain. Delay in recognition can result in significant morbidity or mortality, as well as unnecessary imaging studies and abdominal surgery. Given our patient's history of pancreatitis, the possibility of an alternative cause was not entertained despite lack of objective data. He fell victim to the effects of anchoring bias, or the tendency to make a judgement based on previous information.

Contributors SK and AH are guarantors of this case report and accept responsibility for the overall content of the case report. SK 


\section{Learning points}

- Hereditary angioedema without urticaria should be suspected in patients with recurrent, self-limited abdominal pain. Early diagnosis can reduce future unnecessary imaging studies and surgeries and can prevent future attacks.

- A C4 level is the recommended screening test, and if low the diagnosis is confirmed by a level of $\mathrm{C} 1$-inhibitor less than $50 \%$ of normal (type 1 C1-INH-HAE) or reduced activity of C1-inibitor (type 1 C1-INH-HAE).

- Treatment involves patient education, avoidance of triggers, pharmacotherapy to abort attacks, and discussion of the benefits and risks of preventive medications. ${ }^{2}$ and $\mathrm{AH}$ were involved in the idea to submit this case report and are responsible for writing the case report.

Competing interests None declared.

Patient consent Obtained.

Provenance and peer review Not commissioned; externally peer reviewed.

(C) BMJ Publishing Group Ltd (unless otherwise stated in the text of the article)

2017. All rights reserved. No commercial use is permitted unless otherwise expressly granted.

\section{REFERENCES}

1 Bork K. Angioedema. Immunol Allergy Clin North Am 2014;34:23-31.

2 Cicardi M, Aberer W, Banerji A, et al. Classification, diagnosis, and approach to treatment for angioedema: consensus report from the Hereditary Angioedema International Working Group. Allergy 2014;69:602-16.

Copyright 2017 BMJ Publishing Group. All rights reserved. For permission to reuse any of this content visit

http://group.bmj.com/group/rights-licensing/permissions.

BMJ Case Report Fellows may re-use this article for personal use and teaching without any further permission.

Become a Fellow of BMJ Case Reports today and you can:

Submit as many cases as you like

- Enjoy fast sympathetic peer review and rapid publication of accepted articles

- Access all the published articles

- Re-use any of the published material for personal use and teaching without further permission

For information on Institutional Fellowships contact consortiasales@bmjgroup.com

Visit casereports.bmj.com for more articles like this and to become a Fellow 